\title{
Analysis on the operation mode of China online short - rent enterprises
}

\author{
under the sharing economy \\ Shuxia Dong ${ }^{\mathrm{a}^{*}}$, Yadan Luo ${ }^{a}$, Xiaoxuan Zhang ${ }^{a}$ \\ a School of E\&M,China University of Geosciences, Wuhan, 430074, P.R.China \\ *Corresponding author: Shuxia Dong, Dongshuxia12345@126.com
}

\begin{abstract}
Guided by the Sharing economic mode, so many companies, at home and abroad, have already developed rapidly, such as Mayi, Tujia, Xiaozhu, and so on. Online rental industry is the outstanding representative of the sharing economic development model.This paper aims to analyze both the development model and profit model on China's online rental business. It also aims to find out the prospects of China's online rental business.
\end{abstract}

Key words: sharing economy.short online rental. model analysis.

\section{Introduction}

As the development on the internet and short-term rental market become mature, as the representative in China, Tujia, Mayil developed rapidly on online rental platform. The deal size in online rental market increase rapidly. In 2012, it started with 140million, and it reached to 800 million in 2013, until 2014 it was already up to 3.8billion, and now it will almost reach to 30 billion $^{1}$.

Online rental means that renters book the room on internet or on mobile internet, and pay part or all of the price to the owner online, online platform win the profit based on the rental commissions or advertising. There are many different kinds of house resources, such as apartment, holiday apartment and other personalized short-term accommodation products.

There are two business models on online rental business, B2C and C2C. The rental business will provide the house resources in $\mathrm{B} 2 \mathrm{~B}$, rental income will be divided by the rental company and the landlord proportionally, e.g. tujia. In C2C, the owner will provide the house, owner and the renter will make a deal on the rental platform, and the platform will get the profits from the owner and the advertisement, e.g. mayi.com. 
There are two business models on online rental business, B2C and C2C. The rental business will provide the house resources in $\mathrm{B} 2 \mathrm{~B}$, rental income will be divided by the rental company and the landlord proportionally, e.g. tujia. In C2C, the owner will provide the house, owner and the renter will make a deal on the rental platform, and the platform will get the profits from the owner and the advertisement, e.g. mayi.com.

In July, 2015, in a State Council executive meeting, a policy was clearly mentioned. The access the licensing of 'Internet + ', such as the online vacation rental and the travel car rental business will be relaxed. In November, "On accelerating the development of consumer services for upgrading consumption structure guidance" was promulgated by the State Council. It referred that we should develop the $\mathrm{B} \& \mathrm{~B}$, short stay rental, long-term apartment rental, and determine it as consumer services that the government will provide a lot of supports and will make the consumer services more convenient, exquisite and quality. As the policy is benefit for people to advance the confidence on short-term business, it will lead more people to invest, and it will provide the foundation to the approval on short-term rental. ${ }^{2}$

\section{Domestic main representative online rental business analysis}

The domestic online rental businesses are all based on Airbnb. In China, started with airizu which was invested by Rocket Internet in 2011. However, it couldn’t find a reasonable profit model, end in July 2013. At the same time, tujia, mayi, youtx, xiaozhu were all opened online. Except from this, the specialized search engine, souduanzu, also appeared. Souduanzu was first search engine for the short-stay rental platform, it was supposed to be the 'qunaer' in short-term rental and daily rate.

The paper refers to analysis on Tujia, Xiaozhu and Zhubaijia,.

\section{www.tujia.com}

Overseas housing resources were online on December 5th, 2012. After 2 days, Tujia made a deal with Xiecheng. Until 2015, Tujia was covered on 288 destinations in China and 353 destinations abroad, and had 400,000 housing resources. Meanwhile, Tujia signed a cooperation agreement with nearly 200 government agencies and reached a strategic cooperation with most of the real estate development enterprise in domestic TOP 100. Tujia held 100 billion in assets under management and had more than 800,000 reserved housing resources. Tujia could be so succeed that all base on its well-known brand advantage, creative business model and mighty fine operation capability. 
Tujia mainly provide booking online, Butler Real Estate Services and hosted services. Combined with the specific situation in Chinese, the Sweetome hotel management system is used to provide butler service to the real estate owners in different locations. At the same time, rent the house on www.tujia.com in spare time. Without wasting the daily use, maximize the realization of asset appreciation.

www.mayi.com

Established in November 2011. Access to win the joint investment including Blue Chi venture capital, Sequoia Capital million dollar in 2013.

Mayi is a unique feature of a short rental site managed by ganji website, is a entrepreneurship program on $\mathrm{O} 2 \mathrm{O}$ model, born out of the network short rental channels in ganji website. Registered users can find and book different types of short-stay house all over the country, such as high quality apartments in commercial core area, residential or dormitory around the university, Sea view buildings, garden villas, forest huts and so on.

The early rapid development of Mayi was under the support of Ganji ‘s brand. In 2012, Mayi had accounted for nearly $40 \%$ of the domestic online short rental market ${ }^{3}$, the total number of orders had reached nearly 300,000 one night ${ }^{3}$.

www.xiaozhu.com

As a typical representative of the Airbnb model in China, Xiaozhu is designed to build a green platform system for landlords and tenants with honest, secure online communication, based on the property, mechanisms, personal security and identity identification strategies. This system will make the landlord's spare resources fully utilized and maximized by sharing, while strengthening the social relationships and interactions between landlords and tenants, providing a more humane experience for the tenant than the traditional hotel. Human nature is the characteristics of piglet short rent, to provide cost-effective, family atmosphere, a humane accommodation choice.

In August 2012, Xiaozhu established cooperative strategic with 58, and developed rapidly. The Xiaozhu platform have nearly 70,000 sets of high-quality housing in the domestic 213 cities. Total number of houses in 2015 increased more than 350\% in 2014. More and more young people are beginning to experience the sharing of the economy, living in a stranger's home to experience a humane short rent, Xiaozhu platform has accumulated 3 million active users, turnover in 2015 rose by 500\% in 2014. 


\section{www.zhubaijia.com}

Zhubaijia is a short rental brands for both domestic tourists and overseas, through the sharing of economic mode, provide short-term rental housing services for the Chinese outbound free travel groups. Compared with the Airbnb, Zhubaijia is more familiar with the Chinese tourists, in addition to the provision of short housing services, but also provide All-weather call center customer service, itinerary planning, transfer machine, car rental, booking and tour guide and other travel services. Compared with other domestic online short term rental platforms, it is more focused on the settlement of the needs of Chinese tourists traveling abroad. All around the world, Zhubaijia has millions of sets of selected listings, covered Europe, North America, Oceania, Japan and South Korea, Thailand and other places more than 60 travel hotspot cities, housing resources including from ordinary apartments to special European-style castles. Zhubaijia, expanded the scale of business rapidly in 2014 and 2015. The operating income was 659,000 in 2015, grow 68 times compared with last year,. Revenue growth at the same time, the profit also maintained a certain growth rate, the second half year of 2015 grow about 8.7 times. According the earnings in 2015 showed that the main business income of overseas accounted for $79 \%$ of total income.

\section{Online rental business model}

The business model of the online short term rental business is mainly the B2C and C2C. B2C, Business-to-Customer, the enterprise deal with customers on the internet. C2C, Customer to Customer, means customers deal with each other ${ }^{4}$.

\subsection{Online short-term rental and sharing economy}

Online short-term rental enterprises provide on-line trading platform for landlords and tenants, while it also provide a variety of peripheral services. Cooperating with the independent operation of the offline team or the landlord, it will collect the various types of housing. On the platform, it will provide consumers with house searching and transaction guarantee services. Also there is a platform to use with the Housing Intermediary agency cooperation mode ${ }^{5}$. Short-term rental, is not only bringing a rent rental industry, tourism industry to a new area of development, but also promoted the development of relevant fields of economic theory at the theoretical level, such as, the sharing economy ${ }^{6}$. The Sharing economy is also essentially a business model and also named as a "P2P" model. With the success of Airbnb, Uber and other companies, it attract the current attention and become a popular business model. 


\subsection{Analysis on business model of online short-term rental enterprise and business scope of the enterprise}

In order to enlarge the market share of the domestic online short term rental enterprises, this paper puts forward a proposal that the enterprise should have personalized service, and forms the differentiation competition among other online short rental enterprises. But also different from the online leasing enterprises, the provision of services are slightly different. As shown in table 1:

Table 1 - Business scope of the enterprise

\begin{tabular}{|l|l|l|}
\hline $\begin{array}{l}\text { Online short-term } \\
\text { rental enterprise }\end{array}$ & \multicolumn{1}{|c|}{ Different business scope } & Same business scope \\
\hline Tujia & $\begin{array}{l}\text { The more personalized holiday tourism services, such } \\
\text { as: pick-up, house cleaning, and provide butler service, } \\
\text { hosted service, the professional hotel management will } \\
\text { take care of the house. }\end{array}$ & $\begin{array}{l}\text { The function of short } \\
\text { rental information } \\
\text { display, consultation, } \\
\text { price comparison, } \\
\text { online transaction, } \\
\text { tenant and landlord } \\
\text { evaluation and } \\
\text { sharing through } \\
\text { computer or mobile } \\
\text { end. }\end{array}$ \\
\hline Mayi & $\begin{array}{l}\text { Located a number of tourist destinations, and signed } \\
\text { with Teng LongDong Grand Canyon Tourist scenic } \\
\text { spots. }\end{array}$ & $\begin{array}{l}\text { Highlighting personalized short term rental service } \\
\text { experience, emphasizing the human-oriented in the } \\
\text { process of renting, paying attention to customer } \\
\text { experience, on the basis of leasing service behavior; } \\
\text { practice on the "Tenant protection scheme", "personal } \\
\text { Landlord property protection scheme". }\end{array}$ \\
\cline { 1 - 2 } Zhubaijia & $\begin{array}{l}\text { Focus on providing services for the Chinese who have } \\
\text { short rental needs in foreign countries, as well as local } \\
\text { tickets, attractions and other services. }\end{array}$ & \\
\hline
\end{tabular}

The methods of realizing value of enterprises

(1) Charge a commission on a transaction;

(2) Website advertising costs. Rely on the site's existing traffic resources, carry out a reasonable advertising position. Get the pay from promotion of tourism or housing advertising.

(3) Additional Service fee: Butler service, house cleaning service, pick-up service, etc.

(4) Third-party cooperation charges. such as insurance, scenic tickets, tour guides and other services embedded sales, according to the transaction conditions to collect some fees.

\section{The development of China's online short - rent enterprises}

\subsection{Opportunities and challenges coexist}

The gradually growth on market demand

With the popularity using on smart phones, more and more people are making use of mobile apps to book accommodation. The main force of the short renters are born in 1980 or 1990.

The exploring on business models and profit models

Short-term rental business happened since only five years ago, the business and profitability model is gradually exploring ${ }^{7}$. There are many problems in the market acceptance degree and 
the housing management in China, which need to be strengthened in the credit system construction, meticulous service and so on.

\subsection{Opening up overseas markets}

The domestic short-term rental market develop rapidly, manufacturers are also actively expanding the short rental market overseas at the same time. For example, Zhubaijie currently has opened more than 60 popular destinations around the world short rental business online, has created a overseas short rental platform for Chinese tourists to have a dedicated service ${ }^{8}$. Tujia launched overseas market expansion business. Youtx, Dayu and other companies are trying to do the overseas online short rental market.

\subsection{Promoting the Internet of tourism real estate industry}

In the development of the online short term rental market, it has been combined with the traditional tourism real estate industry, which has improved the industrial form of tourism real estate and promoted the Internet of tourism real estate. The main performance is to promote the vacation apartment can be operated, promote the sharing benefits of vacation villas, promote the birth and prosperity on vacation accommodation.

\section{Conclusions}

In 2016, the short rental business has formed three forms of coexistence pattern, a star-level standards, brand standards and non-standard accommodation. With the standardization of Star-level and brand hotel market saturation, non-standard accommodation short rent ushered in a development opportunity. After 2015 years of development of the small peak, it ushered in a period of rapid development in 2016. Short-term rental has became an important part in the domestic tourism market, and in 2017 short rental enterprises must do the deep analysis and research on the overall development of the industry, user behavior and preferences.

With the development of the market, short rent app downloads, comments and praise has become an important indicator of enterprise product value. In the graduation season, the arrival of the summer, the domestic tourism industry, recruitment industry and many other fields ushered in an outbreak, and for people in different places, accommodation is the key consideration. The hotel is expensive, the short rent market gives people a compromise choice, short rental applications are very rich, including tourism, job hunting, travel, medical treatment, examinations, friends, dating and so on. (Fig. 1) 


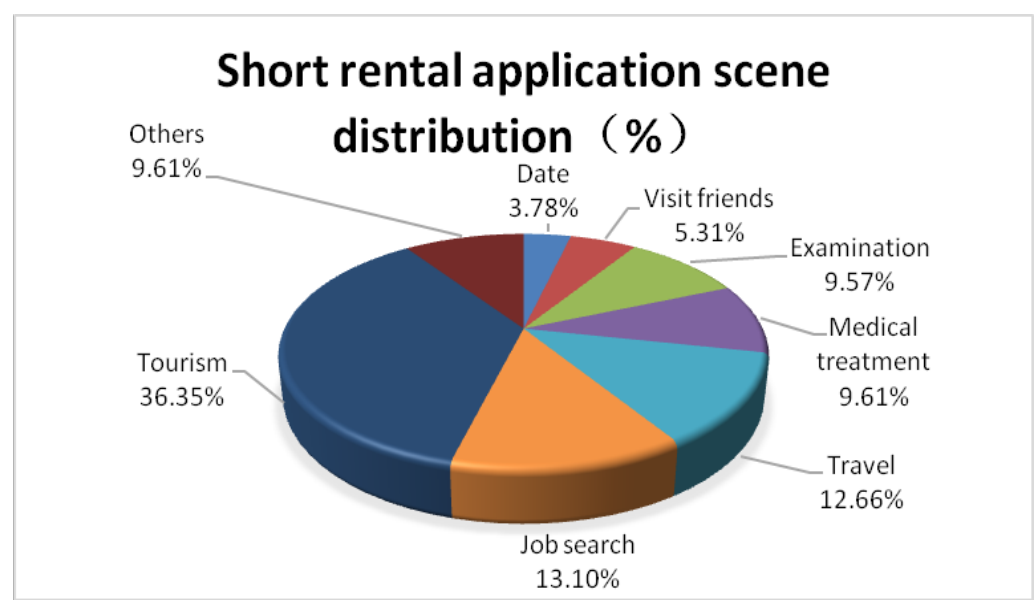

Fig. 1 - Short rental application scene distribution

Domestic short rent market develop till now, basically laid the domestic short rent market initial market pattern. At present, there are two profit models on the domestic short-term rental market, one is information platform, the other is their own control of the full range of services. Although the former is more advantageous in the era of shared economy, and lower in the cost of investment, but latter must be the one to achieve the "replacement of the hotel".

\section{References}

1. Fast-Path Research institute. 2017 online short-term rental market report[R], 2017

2. The National Center for Information Research has shared economic work with China Internet Association. China Share economic Development Report 2016. [R], 2016

3. Iresearch Consulting. 2016 China online holiday leasing market research Report.[R]2016

4. Wang Bin, Lin Danming. The evolution and innovation of e-Business management model [j]. Journal of Shantou University, 2005.Vol.21. No. 4

5. Arain-Offer. Internet business model and strategy,Beijing, Tsinghua University Publishment,2002

6. Ling Cao, Zhang Zan. A study on the development path of "sharing economy" in China _ take online short rent as an example, [J]. Modern management Science-10th issue of the 2014 P36-38.

7. Pan yuemin, Zhang yuanyuan. Shared economy: On-line short-term leasing business model [j]. Technology and business. No. 2014.03. P74-75

8. Yua Le. Review of foreign business model theory [j]. Foreign economics and Management, 2010 (10). 